\title{
Enzymatic biofilm digestion in soil aggregates facilitates the release of particulate organic matter by sonication
}

\author{
Frederick Büks and Martin Kaupenjohann \\ Chair of Soil Science, Department of Ecology, Technische Universität Berlin, Berlin, Germany \\ Correspondence to: Frederick Büks (frederick.bueks@tu-berlin.de)
}

Received: 3 December 2015 - Published in SOIL Discuss.: 18 January 2016

Revised: 13 September 2016 - Accepted: 20 September 2016 - Published: 4 October 2016

\begin{abstract}
The stability of soil aggregates against shearing and compressive forces as well as water-caused dispersion is an integral marker of soil quality. High stability results in less compaction and erosion and has been linked to enhanced water retention, dynamic water transport and aeration regimes, increased rooting depth, and protection of soil organic matter (SOM) against microbial degradation. In turn, particulate organic matter is supposed to support soil aggregate stabilization. For decades the importance of biofilm extracellular polymeric substances (EPSs) regarding particulate organic matter (POM) occlusion and aggregate stability has been canonical because of its distribution, geometric structure and ability to link primary particles. However, experimental proof is still missing. This lack is mainly due to methodological reasons. Thus, the objective of this work is to develop a method of enzymatic biofilm detachment for studying the effects of EPSs on POM occlusion. The method combines an enzymatic pre-treatment with different activities of $\alpha$-glucosidase, $\beta$-galactosidase, DNAse and lipase with a subsequent sequential ultrasonic treatment for disaggregation and density fractionation of soils. POM releases of treated samples were compared to an enzyme-free control. To test the efficacy of biofilm detachment the ratio of bacterial DNA from suspended cells and the remaining biofilm after enzymatic treatment were measured by quantitative real-time PCR. Although the enzyme treatment was not sufficient for total biofilm removal, our results indicate that EPSs may attach POM within soil aggregates. The tendency to additional POM release with increased application of enzymes was attributed to a slight loss in aggregate stability. This suggests that an effect of agricultural practices on soil microbial populations could influence POM occlusion/aggregate stability and thereby carbon cycle/soil quality.
\end{abstract}

\section{Introduction}

Soil organic matter (SOM) comprises $50 \%(\sim 1700 \mathrm{Gt}$, including peat) of the near-surface terrestrial carbon budget, compared to $\sim 813 \mathrm{Gt}$ bound in the atmosphere (Lal, 2008). Beside carbon storage and its influence on the atmospheric $\mathrm{CO}_{2}$ balance, manifold ecological soil functions are mediated by different SOM types like dissolved organic matter (DOM), particulate organic matter (POM), molecular organic matter of organo-mineral associations, colloidal organic matter and coprecipitated molecular organic matter (Kalbitz et al., 2000; Weng et al., 2002; Pokrovsky et al., 2005; Eusterhues et al., 2008). For example, POM is a structural component of soil aggregates, and a nutrient source, and it provides surfaces for microbial growth (Chenu and
Stotzky, 2002; Bronick and Lal, 2005). Parts of the POM are occluded within soil aggregates (Six et al., 2002). Physical isolation protects POM against microbial degradation (Six et al., 2002; Lützow et al., 2006) and maintains its ecological functions, while on the other hand this POM is thought to promote soil aggregation (Bronick and Lal, 2005). Therefore, many benefits of soil POM are linked to soil aggregate stability.

The stability of soil aggregates against shear and compression forces (Skidmore and Powers, 1982) as well as disaggregation caused by water (Tisdall and Oades, 1982) is an integral marker of soil quality (Bronick and Lal, 2005). Since aggregate stability implies pore stability, it results in less soil compactibility (Baumgartl and Horn, 1991; Alaoui 
et al., 2011) and a more dynamic water transport regime in the macropores that reduces erosion caused by surface runoff (Barthes and Roose, 2002). Other benefits in comparison to compacted soils are a higher aeration (Ball and Robertson, 1994) and lower penetration resistance (Bennie and Burger, 1988) causing increased rootability and rooting depth (Bengough and Mullins, 1990; Taylor and Brar, 1991). In addition, micropores within the aggregates enhance water retention.

The occlusion of POM within soil aggregates depends on the properties of the aggregated components. The mineral part of the solid soil matrix is composed of siliceous sand, silt and clay particles, oxides and hydroxides of $\mathrm{Fe}, \mathrm{Al}$ and $\mathrm{Mn}$, and diverse minor minerals. Sticking together, pervaded and coated with multivalent cations and organic constituents (like soluble metabolic products, humic substances, black carbon and other POM) macro-aggregates (> $250 \mu \mathrm{m})$ are formed by direct coagulation or comprised of microaggregates $(<250 \mu \mathrm{m})$ (Bronick and Lal, 2005; Brodowski et al., 2006; Lützow et al., 2006).

The structure-bearing primary particles, precipitates and adsorbed molecules cohere by physico-chemical interactions between (i) permanent charge of mainly the clay mineral fraction; (ii) multivalent cations with small hydrate shells such as $\mathrm{Ca}^{2+}, \mathrm{Fe}^{3+}$ and $\mathrm{Al}^{3+}$; (iii) variable charges of various minerals and SOM; and (iv) variable and permanent dipoles of different soil components. Also carbonates, phosphates and other microbial precipitates force up aggregation and occlusion of POM (Jastrow and Miller, 1997; Bronick and Lal, 2005)

In addition, for a few decades biological structures like bacterial colonies, bacterial pseudomycelia, algae, fungal hyphae and their exudates (e.g., glomalin), roots, and soil fauna have been accepted as a major factor of soil aggregation (Tisdall, 1991; Oades, 1993; Wright and Upadhyaya, 1998; Brown et al., 2000; Chenu and Stotzky, 2002; Rillig, 2004; Bronick and Lal, 2005). Furthermore the role of extracellular polymeric substance (EPS) of bacterial biofilms as an adhesive between soil particles is seen to be of importance (Baldock, 2002; Ashman et al., 2009).

Physical and chemical properties of soil mineral and organic matter allow one to hypothesize a simple spacial model of the inner geometry of soil aggregates, which includes biofilms as links between primary particles (Fig. 1). The biofilm itself is a viscous microenvironment mainly comprised of 90-97\% water (Zhang et al., 1998; Schmitt and Flemming, 1999; Pal and Paul, 2008). The remaining dry mass contains differing ratios of polysaccharides, extracellular DNA (eDNA), proteins and lipids in addition to 10-50\% cell biomass (More et al., 2014). In contrast to "biofilm", EPS terms the extracellular polymeric matrix excluding cells. Extracellular polysaccharides cause the EPS structural stability by means of entanglement and $\mathrm{Ca}^{2+}$ bridging between molecules. So does eDNA (Das et al., 2014). Proteins function as enzymes and structural links stabilizing the polysac-

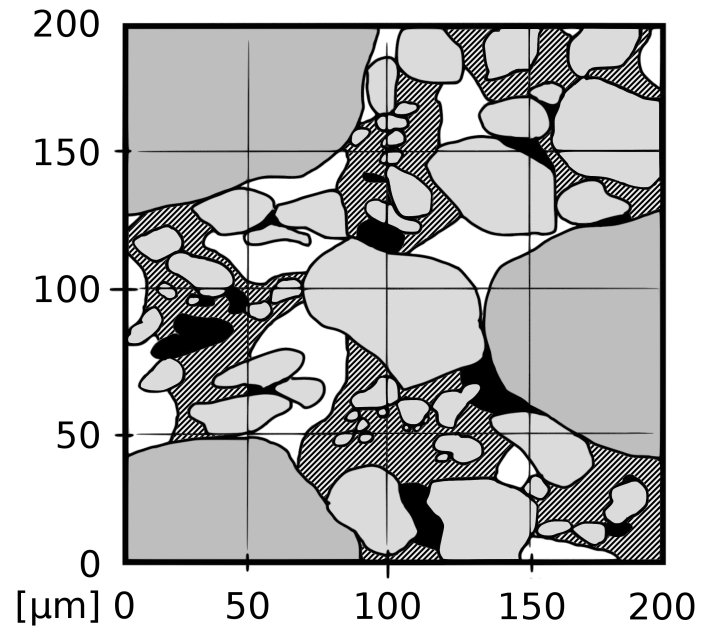

Figure 1. Proposed model of aggregate structure including biofilms in a soil aggregate: sand and silt (both grey) and organic particles (black) stick together by physico-chemical interactions and are bridged by EPS (striped), which additionally stabilizes the soil aggregate structure and the pore space (white).

charide matrix, while lipids act as biosurfactants for bacterial attachment on surfaces (Flemming and Wingender, 2010).

The composition of EPSs is highly variable depending on community composition and environmental cues (Table 1): Redmile-Gordon et al. (2014) measured a natural habitat extracellular polysaccharide concentration of $401 \mu \mathrm{g} \mathrm{g}^{-1}$ dry soil in grassland and $169 \mathrm{\mu g} \mathrm{g}^{-1}$ in fallows. Diverse singleand multi-species biofilms show a proportion of polysaccharides on dry EPSs of up to $95 \%$ (Pal and Paul, 2008; More et al., 2014). Different single- and multi-species biofilms in laboratory cultures and natural soils have a dry EPS eDNA content up to $10 \%$ (More et al., 2014). For forest soils values of 1.95 to $41.1 \mathrm{\mu g} \mathrm{g}^{-1}$ dry soils are known (Niemeyer and Gessler, 2002; Agnelli et al., 2004). Extracellular DNA concentration of other diverse soils ranges between 0.03 and $200 \mathrm{\mu g} \mathrm{g}^{-1}$ dry soil (Niemeyer and Gessler, 2002; Pietramellara et al., 2009), whereas concentrations in soils explicitly used for agriculture are unknown. Extracellular matrix pro-

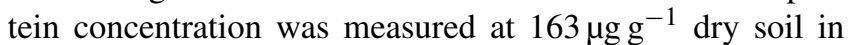
grassland and $43 \mu \mathrm{g} \mathrm{g}^{-1}$ dry soil in fallow (Redmile-Gordon et al., 2014) but can contribute the largest fraction of EPS dry mass, e.g., $60 \%$ (More et al., 2014), and even up to $75 \%$ in Pseudomonas putida biofilms in laboratory cultures (Jahn et al., 1999). The typical proportion of lipids in the EPS dry mass of different non-soil biofilms amounts up to $10 \%$ (More et al., 2014). Sparse molar mass data from different environments comprise $0.5 \times 10^{6}$ to $2 \times 10^{6} \mathrm{Da}$ for polysaccharides (Flemming and Wingender, 2010), $7.75 \times 10^{4}$ to $2.32 \times 10^{7}$ Da for eDNA (DeFlaun et al., 1987) and 750 to $1500 \mathrm{Da}$ for lipids (Munk, 2008).

The extracellular matrix is exuded not only by soil bacteria and archaea but also by fungi and algae. It is engineered 
Table 1. Concentrations and molar masses of biofilm stabilizing macromolecules (polysaccharides - PS, eDNA, lipids and proteins) in different environments.

\begin{tabular}{|c|c|c|c|c|}
\hline $\begin{array}{l}\text { Conc. } \\
\mu \mathrm{g}(\mathrm{g} \text { soil })^{-1}\end{array}$ & $\begin{array}{r}\text { Proportion } \\
\mu \mathrm{g}(100 \mu \mathrm{g} \text { EPS })^{-1}\end{array}$ & $\begin{array}{r}\text { Molar mass } \\
\text { Da }\end{array}$ & Comment & Reference \\
\hline \multicolumn{5}{|c|}{ PS } \\
\hline 169 & & & $\mu \mathrm{g} \mathrm{g}^{-1}$ bare fallow & Redmile-Gordon et al. (2014) \\
\hline \multirow[t]{5}{*}{401} & & & $\mu \mathrm{g} \mathrm{g}^{-1}$ grassland & Redmile-Gordon et al. (2014) \\
\hline & $95 \%$ & & $\%$ of EPS dry mass & More et al. (2014) \\
\hline & $40-95 \%$ & & $\%$ of EPS dry mass & Pal and Paul (2008) \\
\hline & & $2 \times 10^{6}$ & & Chenu and Roberson (1996) \\
\hline & & $0.5-2 \times 10^{6}$ & & Flemming and Wingender (2010) \\
\hline \multicolumn{5}{|c|}{ eDNA } \\
\hline $2.2-41.1$ & & & $\mu \mathrm{gg}^{-1}$ forest soil & Agnelli et al. (2004) \\
\hline 0.08 & & & $\mu \mathrm{gg}^{-1}$ Luvisol & Niemeyer and Gessler (2002) \\
\hline 1.95 & & & $\mu \mathrm{g} \mathrm{g}^{-1}$ forest podzol & Niemeyer and Gessler (2002) \\
\hline \multirow[t]{3}{*}{$0.03-200$} & & & $\mu \mathrm{g} \mathrm{g}^{-1}$ unnamed soil & Pietramellara et al. (2009) \\
\hline & $10 \%$ & & $\%$ EPS dry mass & More et al. (2014) \\
\hline & & $7.75 \times 10^{4}-2.32 \times 10^{7}$ & estuarine and oceanic environments & DeFlaun et al. (1987) \\
\hline \multicolumn{5}{|c|}{ Lipids } \\
\hline \multirow{2}{*}{\multicolumn{2}{|c|}{$10 \%$}} & \multirow[b]{2}{*}{$750-1500$} & \multirow[t]{2}{*}{$\%$ of EPS dry mass } & More et al. (2014) \\
\hline & & & & Abröll and Munk (2008) \\
\hline \multicolumn{5}{|c|}{ Proteins } \\
\hline 43 & & & $\mu \mathrm{gg}^{-1}$ bare fallow & Redmile-Gordon et al. (2014) \\
\hline \multirow[t]{3}{*}{163} & & & $\mu \mathrm{g} \mathrm{g}^{-1}$ grassland & Redmile-Gordon et al. (2014) \\
\hline & $<75 \%$ & & $\%$ of Pseudomonas Putida biofilm & Jahn et al. (1999) \\
\hline & $60 \%$ & & $\%$ EPS dry mass & More et al. (2014) \\
\hline
\end{tabular}

by grazing protozoa, small metazoa, and microbial extracellular enzymes (Battin et al., 2007; Flemming and Wingender, 2010).

The activity of EPS degrading enzymes in natural soils spans up to 2 orders of magnitude: the $\alpha$-glucosidase and $\beta$ galactosidase activity of various soils ranges from 0.00011 to $0.0011 \mathrm{U} \mathrm{g}^{-1}$ and from 0.00017 to $0.0094 \mathrm{U} \mathrm{g}^{-1}$, respectively (Eivazi and Tabatabai, 1988; Acosta-Martinez and Tabatabai, 2000). The lipase activity in coarse mineral soils shows values from $0.3 \mathrm{Ug}^{-1}$ in a sandy soil (Cooper and Morgan, 1981) to $2.09 \mathrm{U} \mathrm{g}^{-1}$ in a Luvisol (Margesin et al., 2000) and up to $5 \mathrm{U} \mathrm{g}^{-1}$ in a Leptosol (Margesin et al., 1999). Data for eDNAse activity in soils are not available.

Not much is known about the contribution of EPS to POM occlusion and aggregate stability in relation to other aggregate stabilizing factors. That is mainly due to methodological reasons: though, e.g., Tang et al. (2011) showed a significant contribution of bacterial growth on aggregate stability, the observations could not definitely be attributed to soil microbial exopolysaccharide production. Redmile-Gordon et al. (2014) subsequently found that the techniques previously used to measure extracellular polysaccharides in soil coextracted large quantities of "random" soil organic matter which confounded estimates of EPS production. Owing to the widespread interest in the role of biofilms on soil fertil- ity, the objectives of this work are (i) to design a selective method for enzymatic biofilm detachment with minor impact on other types of aggregate bonds and (ii) to apply the method to an agricultural soil to provide indications of the influence of biofilm cohesion on POM fixation, which is expected to contribute to aggregate stability (Six et al., 2004).

The method combines a modified enzymatic pretreatment (Böckelmann et al., 2003) with $\alpha$-glucosidase, $\beta$ galactosidase, DNAse and lipase, a determination of the DNA ratio of sessile to suspended cells after enzymatic treatment and an ultrasonication of soil aggregates followed by density fractionation and soil organic carbon (SOC) measurement (Kaiser and Berhe, 2014). The ultrasonication/density fractionation separates SOC into three operational solid fractions: non-occluded free light fraction SOC (fLF-SOC), aggregate-embedded occluded light fraction SOC (oLF-SOC) and colloidal as well as (macro)molecular SOC, which is not detachable from mineral surfaces by the chosen fractionation method and subsumed under heavy fraction (HF-SOC) (Kaiser and Berhe, 2014).

We hypothesize that a destabilization of the EPS matrix occurs during enzymatic treatment. This should result in an increased cell detachment from aggregates. We also expect an increased fLF-SOC release from destabilized aggregates compared to the control and a shift of the oLF-SOC ratio 
from higher to lower binding strength (represented by ultrasonic energy levels) that is interpretable as alteration of soil aggregate stability.

\section{Materials and methods}

\subsection{Soil properties and microbial biomass}

Well-aggregated silty sand (Su3) of a plowed topsoil from a cropland near Berge (Brandenburg, Germany) was air-dried and sieved to obtain a particle size of 0.63 to $2.0 \mathrm{~mm}$ containing mainly macro-aggregates. The aggregates have a $\mathrm{pH}_{\mathrm{CaCl}_{2}}$ of $6.9, \mathrm{C}_{\text {org }}$ of $8.7 \mathrm{mg} \mathrm{g}^{-1}$ and a carbonate concentration of $0.2 \mathrm{mg} \mathrm{g}^{-1}$.

To estimate the soil microbial biomass, first $8 \times 10 \mathrm{~g}$ of soil aggregates was adjusted to $70 \%$ vol soil water content and incubated for $70 \mathrm{~h}$ at $20^{\circ} \mathrm{C}$ in the dark to attain basal respiration. Then, based on DIN EN ISO 14240-2, half of the samples were fumigated with ethanol-free chloroform in an evacuated desiccator for $24 \mathrm{~h}$, whereas the other half remained untreated. Afterwards chloroform was removed and both halves were extracted with $40 \mathrm{~mL}$ of $0.5 \mathrm{M} \mathrm{K}_{2} \mathrm{SO}_{4}$ solution by $30 \mathrm{~min}$ of horizontal shaking and filtered through $0.7 \mu \mathrm{m}$ glass fiber filters. The DOC concentrations of all filtrates were measured by a TOC analyzer (TOC-5050A, Shimadzu); $176 \pm 22 \mu \mathrm{g}$ microbial carbon $\mathrm{g}^{-1}$ dry soil $\left(\mathrm{C}_{\mathrm{mic}}\right)$ was derived from the difference between DOC concentrations of fumigated and non-fumigated samples multiplied by a conversion factor of 2.22 (Joergensen, 1996). Soil bacterial biomass was derived from $\mathrm{C}_{\mathrm{mic}}$ as $352 \pm 44 \mathrm{mg} \mathrm{kg}^{-1}$ assuming 0.5 as a ratio of $\mathrm{C}_{\text {mic }}$ to total cell dry mass (Bratbak and Dundas, 1984).

\subsection{Detachment scenarios}

Four degradative enzymes were selected on the basis of soil $\mathrm{pH}$ and temperature used for catalytic unit definition $\left(T_{\mathrm{def}}\right): \alpha$-glucosidase from Saccharomyce cerevisiae (Sigma-Aldrich, $\mathrm{pH}_{\mathrm{opt}} 6$ to $6.5, T_{\mathrm{def}}=37^{\circ} \mathrm{C}$, product number G0660) hydrolyzes terminal $\alpha$-1,4-glycosidic linkages in polysaccharides as $\beta$-galactosidase from Escherichia coli (Sigma-Aldrich, $\mathrm{pH}_{\text {opt }} 6$ to $8, T_{\text {def }}=37^{\circ} \mathrm{C}$, product number G5635) does with $\beta$-glycosidic bonds. Lipase from porcine pancreas (Sigma-Aldrich, $\mathrm{pH}_{\text {def }} 7.7, T_{\text {def }}=37^{\circ} \mathrm{C}$, product number L0382) splits fatty acids from lipids via hydrolysis but does not digest phospholipids, which are part of bacterial membranes. DNAse I from bovine pancreas $\left(\mathrm{pH}_{\mathrm{def}} 5\right.$, $T_{\text {def }}=25^{\circ} \mathrm{C}$, product number D5025) breaks the phosphodiester linkages between nucleotides of DNA as an endonuclease. Proteases were not used because of their unspecificity and therefore incalculable influence on the other applied enzymes.

The literature shows a wide range of target concentrations related to these enzymes in different soils. As we do not know target concentrations of our soil (due to a lack of extraction methods), we considered the largest published values (Table 2) of EPS content $\left(\xi_{\mathrm{EPS}}^{\max }\right)$ and enzyme target dry mass contents $\left(\xi_{\text {target }}^{\max }\right)$ from the literature. Further, as bacterial dry mass $\left(\xi_{\text {cell }}^{\min }\right)$ and target molar masses $\left(M_{\text {target }}^{\min }\right)$ vary as well, here we choose the minimum percentage and the smallest mass, respectively. These values conduce to a "worst-case" point of view with a maximum of enzyme targets. Any other boundary conditions such as ion activity, diffusion rates or metabolization of enzymes by soil organisms were disregarded.

Calculated by Eq. (1)

Unit $_{\text {target }}=\frac{c_{\text {cell }} \cdot q \cdot \xi_{\mathrm{EPS}}^{\max } \cdot \xi_{\mathrm{target}}^{\max } \cdot m_{\mathrm{sample}}}{\xi_{\mathrm{cell}}^{\min } \cdot M_{\mathrm{target}}^{\min } \cdot t}$

with variables listed in Tables 2 and 3, sufficient enzymes were provided to digest the expected EPS concentration in five scenarios: in the E1 scenario $c_{\text {cell }}$ was given by the results of fumigation extraction. In the E2 scenario a bacterial dry mass of $500 \mathrm{~g} \mathrm{~m}^{-2}$ in the upper $30 \mathrm{~cm}$ is considered, which is assumed to be the maximum for middle and northern European soils (Brauns, 1968). Supposing a soil bulk density of $1.4 \mathrm{~g} \mathrm{~cm}^{-3}$, a $c_{\text {cell }}$ of $1190.5 \mu \mathrm{g} \mathrm{g}^{-1}$ dry soil is given. Although the soil bulk density of the soil aggregate samples is $\sim 1.15 \mathrm{~g} \mathrm{~cm}^{-3}$, we decided to use the soil bulk density of the original soil, which is in the normal range of sandy silk soil $\left(\sim 1.40 \mathrm{~g} \mathrm{~cm}^{-3}\right)$ (Chaudhari et al., 2013). This is due to the fact that biofilm populations are mentioned to be mainly located in soil aggregates (Nunan et al., 2003) and is in accordance with the "worst-case" approach. The E3 scenario uses a 100-fold excess ( $q=100$, Table 3$)$ of the enzyme activities applied in the E2 scenario, whereas the E4 scenario contained a 2820 -fold excess, which is slightly higher than activities used in Böckelmann et al. (2003). Enzyme-free samples (E0) were used as a control.

\subsection{Release of POC}

Fifteen grams of air-dried soil aggregates were incubated in five replicates per scenario with $3.4 \mathrm{~mL}$ of highly concentrated artificial rainwater (ARW: $0.2 \mathrm{mM} \mathrm{NH}_{4} \mathrm{NO}_{3}, 0.3 \mathrm{mM}$ $\mathrm{MgSO}_{4} \times 7 \mathrm{H}_{2} \mathrm{O}, 0.5 \mathrm{mM} \mathrm{CaCl}_{2} \times 2 \mathrm{H}_{2} \mathrm{O}, 0.5 \mathrm{mM} \mathrm{Na}_{2} \mathrm{SO}_{4}$, $15 \mathrm{mM} \mathrm{KCl}, \mathrm{pH}$ 5.7) for 3 days at $20^{\circ} \mathrm{C}$ in the dark to establish basal respiration and avoid slaking in the following preparation steps. After incubation $2.5 \mathrm{~mL}$ of ARW containing enzymatic units according to Table 3 was added to the samples. By means of a following incubation at $37^{\circ} \mathrm{C}$, enzymes were put to work near their catalytic optimum for $1 \mathrm{~h}$, which is proven to be sufficient for biofilm degradation (Böckelmann et al., 2003). After this enzymatic pretreatment, $67.2 \mathrm{~mL}$ of $1.67 \mathrm{~g} \mathrm{~cm}^{-3}$ dense sodium polytungstate (SPT) solution was added, resulting in a density cut-off of $1.6 \mathrm{~g} \mathrm{~cm}^{-3}$, and samples were stored for $30 \mathrm{~min}$ to allow SPT diffusion into the aggregates. Then samples were cen- 
Table 2. Variables used for the calculation of enzyme units needed for biofilm target decomposition and scenario parameters shared by all variants.

\begin{tabular}{|c|c|c|}
\hline$c_{\text {cell }}$ & {$\left[\mu \mathrm{gg}^{-1}\right]$} & bacterial dry mass per gram dry soil \\
\hline$q$ & {$[-]$} & enzyme concentration multiplier \\
\hline$\xi_{\mathrm{EPS}}^{\max }$ & {$[-]$} & $\begin{array}{l}\operatorname{maximum} \text { ratio of EPS dry mass per total biofilm dry mass } \\
\left(\xi_{\text {EPS }}^{\max }=0.9^{\mathrm{a}}\right)\end{array}$ \\
\hline$\xi_{\text {target }}^{\max }$ & {$[-]$} & $\begin{array}{l}\text { maximum ratio of enzyme target per EPS dry mass } \\
\left(\xi_{\text {polysaccharides }}^{\max }=0.95^{\mathrm{b}}, \xi_{\text {lipids }}^{\max }=0.1^{\mathrm{a}} \text { and } \xi_{\mathrm{eDNA}}^{\max }=0.1^{\mathrm{a}}\right)\end{array}$ \\
\hline$m_{\text {sample }}$ & {$[\mathrm{g}]$} & sample mass \\
\hline$\xi_{\text {cell }}^{\min }$ & {$[-]$} & minimum ratio of bacterial dry mass per total biofilm dry mass $\left(\xi_{\text {cell }}^{\min }=0.1^{\mathrm{a}}\right)$ \\
\hline$M_{\text {target }}^{\min }$ & {$\left[\mu \mathrm{g} \mu \mathrm{mol}^{-1}\right]$} & $\begin{array}{l}\text { minimum molar mass of enzyme target } \\
\left(M_{\text {polysaccharides }}^{\min }=0.5 \times 10^{6 \mathrm{c}}, M_{\text {polysaccharides }}^{\min }=700^{\mathrm{d}}, M_{\mathrm{eDNA}}^{\min }=7.75 \times 10^{4 \mathrm{e}}\right)\end{array}$ \\
\hline$t$ & [min] & incubation time \\
\hline
\end{tabular}

${ }^{a}$ More et al. (2014). ${ }^{\mathrm{b}}$ Pal and Paul (2008). ${ }^{\mathrm{c}}$ Flemming and Wingender (2010). ${ }^{\mathrm{d}}$ Abröll and Munk (2008). ${ }^{\mathrm{e}}$ DeFlaun et al. (1987).

Table 3. Specific scenario parameters of the variants E0, E1, E2, E3 and E4.

\begin{tabular}{|c|c|c|c|c|c|c|}
\hline & & E0 & E1 & E2 & E3 & E4 \\
\hline$c_{\text {cell }}$ & {$\left[\mu \mathrm{g} \mathrm{g}^{-1}\right.$ dry soil] } & 352 & 352 & 1191 & 1191 & 1191 \\
\hline$q$ & {$[-]$} & 1 & 1 & 1 & 100 & 2820 \\
\hline \multirow{2}{*}{$\mathrm{U}_{\alpha \text {-glucosidase }}^{\max }$} & [U g ${ }^{-1}$ dry soil] & 0.00000 & 0.00010 & 0.00034 & 0.03393 & 0.95683 \\
\hline & {$\left[\mu \mathrm{g} \mathrm{g}^{-1}\right.$ dry soil $]$} & 0.00000 & 0.00080 & 0.00272 & 0.27144 & 7.65464 \\
\hline \multirow{2}{*}{$\mathrm{U}_{\beta \text {-galactosidases }}^{\max }$} & [U g ${ }^{-1}$ dry soil] & 0.00000 & 0.00010 & 0.00034 & 0.03393 & 0.95683 \\
\hline & {$\left[\mu \mathrm{g} \mathrm{g}^{-1}\right.$ dry soil $]$} & 0.00000 & 0.00020 & 0.00068 & 0.06786 & 1.91366 \\
\hline \multirow{2}{*}{$\mathrm{U}_{\text {lipids }}^{\max }$} & [U g ${ }^{-1}$ dry soil] & 0.00000 & 0.00754 & 0.02551 & 2.55102 & 71.93876 \\
\hline & {$\left[\mu \mathrm{g} \mathrm{g}^{-1}\right.$ dry soil $]$} & 0.00000 & 0.00038 & 0.00126 & 0.12551 & 3.59694 \\
\hline \multirow{2}{*}{$\mathrm{U}_{\mathrm{eDNA}}^{\max }$} & {$\left[\mathrm{Ug}^{-1}\right.$ dry soil $]$} & 0.00000 & 0.00007 & 0.00023 & 0.02304 & 0.64973 \\
\hline & {$\left[\mu \mathrm{g} \mathrm{g}^{-1}\right.$ dry soil] } & 0.00000 & 0.00004 & 0.00012 & 0.01152 & 0.32487 \\
\hline
\end{tabular}

trifuged for $26 \mathrm{~min}$ with $3569 \mathrm{~g}$. Sodium polytungstate solution with floating fLF was filtered through a $1.5 \mu \mathrm{m}$ pore size glass fiber filter to capture LF particles. Afterwards following Golchin et al. (1994) aggregate samples were consecutively disaggregated in four steps by application of each $50 \mathrm{~J} \mathrm{~mL}^{-1}$ of ultrasonic energy (Branson ${ }^{\odot}$ Sonifier 250) for $1 \mathrm{~min} 15 \mathrm{~s}$. The energy output was determined by measuring the heating rate of water inside a Dewar flask (Schmidt et al., 1999). Every treatment cycle consisted of ultrasonication, centrifugation for $26 \mathrm{~min}$ with $3569 \mathrm{~g}$ and filtering of SPT solution through a $1.5 \mu \mathrm{m}$ pore size glass fiber filter to capture the LF. Afterwards the LFs and the remaining soil matrix ("sediment", consisting of oLF bonded $>150 \mathrm{~J} \mathrm{~mL}^{-1}$ and the HF) were frozen, lyophilized, ground and dried at $105^{\circ} \mathrm{C}$. Total amount of fraction carbon was determined using an Elemen- tar Vario EL III CNS Analyzer and the absence of carbonates was proved, respectively.

\subsection{Release of bacterial DNA}

The release of bacterial cells into the solution was quantified using a FastDNA ${ }^{\mathrm{TM}}$ SPIN Kit for Soil and quantitative realtime PCR.

Therefore $45 \mu \mathrm{L}$ of ARW was added directly to $0.1 \mathrm{~g}$ of air-dried aggregates. The samples were sterilely incubated in duplicate at $20^{\circ} \mathrm{C}$ for 3 days in the dark in a closed FastPrep Lysing Matrix E tube during the run to basal respiration. Then $30 \mu \mathrm{L}$ of ARW containing enzymatic units according to Table 3 was distributed equally to the aggregates' surfaces. The samples were incubated for $1 \mathrm{~h}$ at $37^{\circ} \mathrm{C}$ in a heating block, cooled down on ice to decrease enzyme activity and washed three times in $1 \mathrm{~mL}$ of ARW not by shaking 
but gently rotating along the tube's longitudinal axis to separate detached and planktonic cells from the soil matrix. Supernatants of all three washing steps were removed carefully with a pipette, pooled and centrifuged at $13000 \mathrm{~g}$ for $15 \mathrm{~min}$ at $4{ }^{\circ} \mathrm{C}$. Then the supernatant was discarded, the pallet resuspended in $200 \mu \mathrm{L}$ ARW and transferred to another FastPrep Lysing Matrix E tube. Both soil and washing ARW samples were extracted and purified at $4{ }^{\circ} \mathrm{C}$ following the FastDNA ${ }^{\mathrm{TM}}$ SPIN Kit for Soil manual. All DNA samples were stored at $-20^{\circ} \mathrm{C}$ for further use. A direct subsampling from the aggregate stability experiment was rejected due to its destructive capability regarding aggregates. Temperature, substrate, $\mathrm{pH}$ and water content of the DNA experiment were similar to the incubation of samples for the measurement of aggregate stability. Further differences (e.g., soil volume) were disregarded.

Amplification of 10-fold diluted DNA samples was performed using a C1000 Touch Thermal Cycler (BioRad). According to the reference for SG qPCR Master Mix (Roboklon) thermocycling comprised an initial denaturation at $95^{\circ} \mathrm{C}$ for $10 \mathrm{~min}$ as well as 55 cycles of $15 \mathrm{~s}$ of denaturation at $95^{\circ} \mathrm{C}, 20 \mathrm{~s}$ of annealing at $49^{\circ} \mathrm{C}$ and $30 \mathrm{~s}$ of elongation at $72{ }^{\circ} \mathrm{C}$. The reaction mix contained $1 \mu \mathrm{L}$ PCR- $\mathrm{H}_{2} \mathrm{O}, 12.5 \mu \mathrm{L}$ SG qPCR MasterMix, each $0.75 \mu \mathrm{L}$ of a $20 \mu \mathrm{mol} \mathrm{L}^{-1}$ solution of the universal bacterial primers $63 \mathrm{f}$ (5'-CAGGCCTAACACATGCAAGTC$3^{\prime}$ ) and 341r (5'-CTGCTGCCTCCCGTAGG-3') (Muyzer et al., 1993; Marchesi et al., 1998) and $10 \mu \mathrm{L}$ template DNA. Escherichia coli 16s DNA solution containing 10000 copies $\mu \mathrm{L}^{-1}$ was used as qPCR standard in steps of 10 -fold diluted concentration from $10^{6}$ to $10^{2}$ copies $\mu \mathrm{L}^{-1}$.

\subsection{Statistics}

For evaluation of the light fraction SOC (LF-SOC) release, mean values, and standard deviations were calculated. Parallels of each variant were positively tested to provide normal distribution and evidence of variance homogeneity (ShapiroWilk test, Levene test, both $p>0.05$, data not shown). Oneway analysis of variance (ANOVA) was applied followed by Tukey test to clarify significant $(p<0.05)$ differences in LFSOC release between variants of each energy level. Results of bacterial DNA release were presented as duplicates.

\section{Results}

\subsection{Release of particulate organic carbon (POC)}

The relative LF carbon release from soil aggregate samples after different enzymatic treatments is shown in Fig. 2. The proportionate $\mathrm{C}$ of each captured fraction is defined as $\mathrm{C}_{\text {frac }}$ $\mathrm{C}_{\Sigma}^{-1}$, in which $\mathrm{C}_{\text {frac }}$ is the release of LF-SOC per energy level or - in the case of the sediment - the organic carbon remaining in the soil matrix. $\mathrm{C}_{\Sigma}$ is the total SOC of all separated LFs and the sediment. Averaging all treatments, around $79 \%$

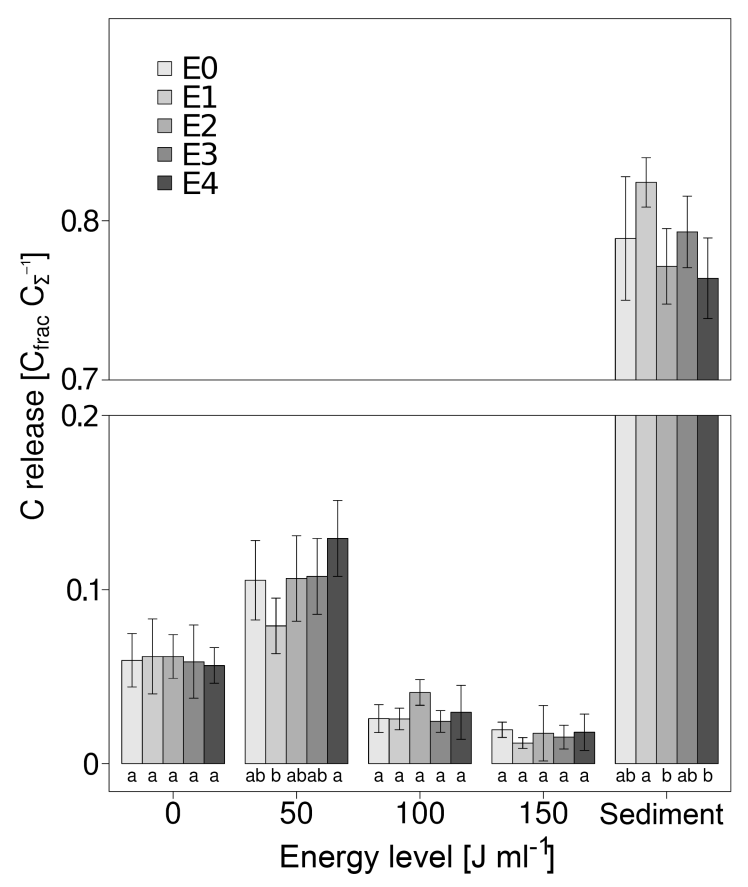

Figure 2. Relative POC release of treatments (E0, E1, E2, E3, E4) at different energy levels $\left(0,50,100,150 \mathrm{~J} \mathrm{~mL}^{-1}\right.$, sediment), illustrated by Tukey test characters $(a, a b, b)$. Data are shown as mean values and standard deviations $(n=5)$.

of $\mathrm{C}_{\Sigma}$ remains in the sediment, whereas the bulk of LF-SOC is released as weakly bound $\mathrm{OLF}\left(50 \mathrm{~J} \mathrm{~mL}^{-1}\right)$ and fLF. Only around $4.5 \%$ of $\mathrm{C}_{\Sigma}$ is detached at 100 and $150 \mathrm{~J} \mathrm{~mL}^{-1}$.

None of the enzymatic treatments altered the quantity of fLF-SOC released in the absence of sonication $\left(0 \mathrm{~J} \mathrm{~mL}^{-1}\right)$. In contrast, visible differences to the control were shown for E1 (decrease, $p=0.34$ ) and E4 (increase, $p=0.42$ ) at mild sonication $\left(50 \mathrm{~J} \mathrm{~mL}^{-1}\right)$, whereas $\mathrm{E} 2(p=1.00)$ and $\mathrm{E} 3$ $(p=1.00)$ are very similar to the control. The difference between E1 and E4 was statistically significant $(p=0.01)$ as indicated by the Tukey test, and the addition of the highest enzyme concentration (E4) caused the release of about $63 \%$ more oLF-SOC than occurred with the addition of the lowest concentration (E1). Released LF-SOC at 100 and $150 \mathrm{~J} \mathrm{~mL}^{-1}$ is not different among treatments. Only the E2 scenario shows any tendency of increased oLF-SOC release at $100 \mathrm{~J} \mathrm{~mL}^{-1}$ compared to the other treatments $(p=0.07$ compared to E3).

The sediment represents the SOC remaining unextractable at $\leq 150 \mathrm{~J} \mathrm{~mL}^{-1}$ and accordingly shows a trend to decrease with increasing enzyme activity. In relation to the control, nearly the whole alteration in the oLF-SOC releases of E1 and $\mathrm{E} 4$ at $50 \mathrm{~J} \mathrm{~mL}^{-1}$ as well as $\mathrm{E} 2$ at $100 \mathrm{~J} \mathrm{~mL}^{-1}$ comes from the sediment fraction, but hardly from the other LFs. However, opposite reallocation of SOC between fractions due to converse physico-chemical effects can only be observed in 


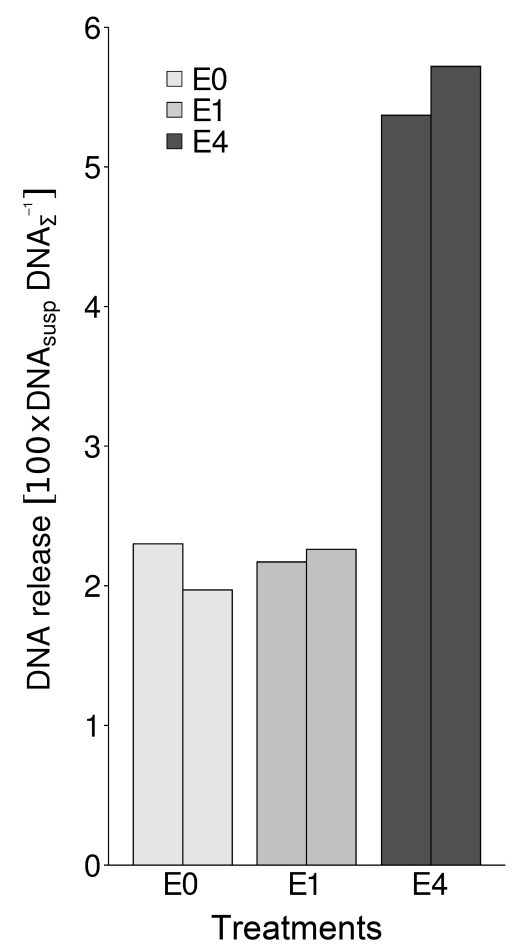

Figure 3. Relative bacterial DNA release from soil aggregates after treatments E0, E1 and E4 defined as $100 \times$ ratio of bacterial DNA from suspended cells (DNAsusp) to total bacterial DNA from suspended cells, sessile cells $\left(\mathrm{DNA}_{\Sigma}\right)$ and the EPSs remaining upon the soil matrix.

sum. Therefore alterations must be considered as net $\mathrm{C}$ transfer between stability fractions.

Cumulating LF-SOC releases of all energy levels, E1 shows a reduction by $16 \%$ compared to the control (3.3\% of $\mathrm{C}_{\Sigma}$ ), whereas $\mathrm{E} 4$ was increased by $10 \%\left(2.2 \%\right.$ of $\left.\mathrm{C}_{\Sigma}\right)$. The strongest enzymatic treatment (E4) caused the release of about $58 \%\left(0.49 \mathrm{mg} \mathrm{g}^{-1}\right.$ dry soil $)$ more cumulated LF-SOC than occurred with scenario E1.

\subsection{Release of bacterial DNA}

The relative DNA release after enzymatic treatment, as pictured with the treatments E0, E1 and E4 in Fig. 3, is defined as the ratio of extracted DNA from suspended bacterial cells $\left(\mathrm{DNA}_{\text {susp }}\right)$ to the sum of DNA extracted from suspended and sessile bacterial cells and the remaining EPSs $\left(\mathrm{DNA}_{\Sigma}\right)$ multiplied by 100 . While there was no difference in relative DNA release in the wash of control and low enzyme additions, treatment $\mathrm{E} 4$ caused an increase to more than double the DNA content of either E0 or E1, which amounts to $5.6 \%$ of total DNA. This increase is caused by both an increase in released bacterial DNA from suspended bacterial cells and a decrease in eDNA remaining in washed soil.

\section{Discussion}

We found that increasing the quantity of enzymes applied to aggregates led to increased release of LF-SOC when aggregates were sonicated. This detachment is explained by the following mechanism: the enzyme mix flows into the unsaturated pore space. From there $\alpha$-glucosidase, $\beta$-galactosidase, DNAse and lipase diffuse into the biofilm matrix, where structural components like polysaccharides, eDNA and lipids are digested as approved for diverse enzymes and enzyme targets in ecological and medical studies (Böckelmann et al., 2003; Walker et al., 2007). We propose a simple spacial model to explain the observed findings: the biofilm bridges gaps between organic and mineral primary particles, connects them in addition to other physico-chemical bondings and builds a restructured pore system inside the aggregate (Fig. 1). As macromolecular biofilm components yield EPS as a viscoelastic structure (Sutherland, 2001), their digestion causes a loss in EPS viscosity and thereby should reduce forces involved in the occlusion of POM. The effect is expected to grow with increasing enzyme activity until the whole EPS matrix is dispersed.

In the following, LF-SOC is interpreted as SOC from released POM, since the share of both adsorbed DOM and colloids on captured dry mass is considered to be negligible after SPT treatment. Furthermore, LF-SOC transferred from the sediment fraction to light fractions due to enzymatic treatment is also interpreted as POM; in contrast mineralassociated organic matter of the HF is not assumed to be extractable at the applied energies (Cerli et al., 2012).

In accordance with the model, measured oLF-SOC releases indicate a trend for increased POM release with increasing enzyme addition (Fig. 2). The E4 scenario shows that relative oLF-SOC release increased by $63 \%\left(5 \%\right.$ of $\left.\mathrm{C}_{\Sigma}\right)$ compared to $\mathrm{E} 1$ at $50 \mathrm{~J} \mathrm{~mL}^{-1}$, but its release is similar to the mean of the other treatments at 0,100 and $150 \mathrm{~J} \mathrm{~mL}^{-1}$. Noticeable deviations of E1 and E4 from the control do not match the usual significance criteria $(p<0.05)$. However, the increase of the relative oLF-SOC release in the E4 scenario compared to the control is predominantly related to an equally lower $\mathrm{C}$ content of the sediment but no decrease in the 100 and $150 \mathrm{~J} \mathrm{~mL}^{-1}$ fractions. This points to a strong (oLF $>150 \mathrm{~J} \mathrm{~mL}^{-1}$ ) intra-aggregate fixation of POM due to enzyme targets, which is weakened by enzymatic treatment.

The relation of LF-SOC release with enzymatic biofilm digestion is supported by the comparison of bacterial DNA releases between the treatments (Fig. 3). This indicates that applied enzymes are targeting biofilm components and release bacterial cells: the E4 scenario shows EPS digestion and additional cell release leading to a doubled relative DNA release compared with the control and E1. However, considering that most of the soil bacteria are expected to live in biofilms (Davey and O'toole, 2000), the total DNA release of only $5.6 \%$ in the E4 scenario is too low for total biofilm digestion. Hence, biofilm detachment caused by E4 is still 
likely to be incomplete and the increased oLF-SOC release of E4 only results from a partial soil biofilm detachment. We conclude that there is a slight influence of enzymatic treatment on the occlusion of POM at enzyme concentrations exceeding natural concentrations. This conforms to results of Böckelmann et al. (2003), which indicate that a treatment with enzyme concentrations of near that of E4 is sufficient to destabilize biofilms within $1 \mathrm{~h}$.

The incomplete biofilm detachment can be explained by the reduction of enzyme activity due to interaction with the soil matrix. Based on our calculations enzyme concentrations of mix E1 should have been sufficient for total biofilm digestion within time of application $(1 \mathrm{~h})$ - as long as there are no other factors reducing enzyme efficiency. As surveys of natural soils show enzyme concentrations up to mix E3 (Cooper and Morgan, 1981; Eivazi and Tabatabai, 1988; Margesin et al., 1999; Acosta-Martinez and Tabatabai, 2000; Margesin et al., 2000), such factors might be reasonably assumed. After addition to the soil sample, enzymes must enter the EPS matrix by diffusion. Therefore parts of the enzymes probably do not reach the biofilm due to inhibited diffusion. Beside diffusion, sorption and decomposition could play a major role in reducing enzyme efficiency. Whereas turn-over rates of soil enzymes have not yet been assessed, extended stabilization of active enzymes over time on soil mineral and organic surfaces is reported (Burns et al., 2013). This mechanism could explain immobilization of enzymes off the biofilm and high measured soil enzyme concentrations from the literature in face of still existing biofilms. After penetration of biofilms, (macro)molecules interfere with EPS components depending on molecular size, charge and biofilm structure (Stewart, 1998; Lieleg and Ribbeck, 2011), which strongly influences decay rates of enzymes. Due to these boundary conditions, quantification of the relation of enzyme concentration and POC release was not possible in this work.

The trend for increased POM release with increasing enzyme addition was only broken by the control treatment. This could probably be explained by pre-incubation of soil aggregates given $0.2 \mathrm{mM} \mathrm{NH} \mathrm{NHO}_{3}$ and further addition of $\mathrm{NH}_{4} \mathrm{NO}_{3}$ with enzyme application: Redmile-Gordon et al. (2015) proposed that low $\mathrm{C} / \mathrm{N}$ ratios of substrates available to soil microorganisms reduce cell-specific EPS production rates and may trigger microbial consumption of EPSs to acquire $\mathrm{C}$ for cell-growth, which could weaken the biofilm. The observations leading to this proposed dynamic were also found by addition of $\mathrm{NH}_{4} \mathrm{NO}_{3}$. In the present study, $\mathrm{NH}_{4} \mathrm{NO}_{3}$ was applied with all treatments including the control (which also received no $\mathrm{C}$ from enzyme provision). The lowest $\mathrm{C} / \mathrm{N}$ ratio in the control soils may itself have sustained EPS consumption and repressed reconstruction of the EPSs, contributing to the higher than expected release of POM from the control soil with sonication at $50 \mathrm{~J} \mathrm{~mL}^{-1}$ and the break in the trend for increasing POM release with increasing enzyme addition.
Enzyme $\mathrm{C}$ in $\mathrm{E} 1$ to $\mathrm{E} 4$ could be used as microbial $\mathrm{C}$ source. The addition of $\mathrm{C}$ increases the $\mathrm{C} / \mathrm{N}$ ratio and has been shown to lead to soil aggregate stabilization (Watts et al., 2005; Tang et al., 2011). Decay rates of enzymes in soil are unknown but needed for a more accurate estimation of enzyme $\mathrm{C}$ as a fast energy and carbon source.

Under certain conditions POC release is indicative of soil aggregate stability. Generally, aggregate stability is characterized by determining the reduction in aggregate size after application of mechanical force. The commonly used methods are dry and wet sieving. However, the destruction of soil aggregates by ultrasonication has an advantage over these methods, which is the quantification of the applied energy (North, 1976). It is used for studying reduction of aggregate size (Imeson and Vis, 1984) as well as detachment of occluded POC (Golchin et al., 1994). Kaiser and Berhe (2014) reviewed 15 studies using ultrasonication of soil aggregates in consideration of its destructiveness to the soil mineral matrix and occluded POM. They found destruction of POM at applied energy levels $>60 \mathrm{~J} \mathrm{~mL}^{-1}$, destruction of sand-sized primary particles at $>710 \mathrm{~J} \mathrm{~mL}^{-1}$ and of smaller mineral particles at even higher energy levels. We used this method of gentle POM detachment from soil aggregates to measure the oLF-SOC release as a result of mechanical force and linked it to aggregate stability. Since Cerli et al. (2012) have shown that the release of free and occluded light fractions strongly depends on soil properties like mineralogy, POM content, composition and distribution, this method is restricted to comparison of soils being similar in these properties. Having regard to this restriction, the trend for increase of oLFSOC release over increasing enzyme additions demonstrates an alteration of soil aggregate stability.

Although our results give slight evidence for the influence of biofilms on aggregate stability, they have to be recognized with restrictions to full quantifiability:

1. The enzyme concentration hypothetically needed to disperse the whole soil sample EPS matrix depends on diverse boundary conditions like the concentration of enzyme targets, environmental conditions such as $\mathrm{pH}$, temperature as well as ion activity and delay factors such as low diffusion, kinetic influence or metabolization of enzymes by soil organisms.

2. Underlying enzyme kinetics were measured by the producer using pure targets for unit definition, while biofilm targets are much more diverse and soil matrix could interfere.

3. Alternative enzyme targets might be reasonably assumed within the complex chemism of the soil matrix. Released organic cytoplasm molecules of lysed cells can be excluded to be an additional enzyme target due to their low concentration. On the other hand, enzyme specificity to EPS targets in face of the organic soil matrix is unbeknown. 
4. The decrease of extracted POM mass due to biofilm erasement from surfaces is suggested to be low but could cause underestimation of POM release especially in scenario E4. In contrast, a direct contribution of enzyme $\mathrm{C}$ to the POC release can be refuted. Even in the case of complete adsorption to the POM of only one fraction, the highest enzyme concentration (E4) would result in additional $13.5 \mu \mathrm{g}$ enzyme $\mathrm{g}^{-1}$ dry soil being $<0.4 \%$ of the smallest extracted POM fraction (Table 3).

5. Regarding DNA release measurement as well, data are semi-quantitative, since quantification of the detachment effect is limited by a potential adherence of detached cells to soil particles after washing (Absolom et al., 1983; Li and Logan, 2004). Thus, cell release could be underestimated as biofilm detachment increases.

Many of these uncertainties are owed to the high complexity of the soil system. Enzymes were applied in concentrations 4 orders of magnitude higher than calculated from actual $C_{m i c}$ and even 1-2 orders of magnitude higher than values from the literature. Incomplete biofilm removal indicated by the release of maximum 5.5\% DNA from the soil matrix may suggest that the pooled influence of the disregarded boundary conditions on enzymatic detachment efficiency is large.

However, these results give a first though still vague insight into the fundamental processes underlying POM occlusion. A slight release of occluded POM coupled with increased bacterial DNA release after treatment with high enzyme concentrations underpins the assumption that biofilm is involved in POM occlusion being a stabilizing agent of soil aggregates as proposed in a review by Or et al. (2007). The apparent increase of POC release caused by the digestion of EPS components suggests biofilm relevance in soil ecosystems, e.g., in terms of soil-aggregate related functions like soil water and $\mathrm{C}$ dynamics, mechanical stability and rootability. However, the statistical power of this introductory work is low and a more quantitative analysis of the relation of enzymatic EPS detachment and POM release would require deeper knowledge of enzyme dynamics in soil, more replicate samples, additional enzyme concentrations and probably inclusion of soils from different land use. However, this was beyond the scope of the present study.

\section{Conclusions}

Extracellular polymeric substance (EPS) was shown to be a promising candidate factor of aggregate stability. Our experimental results suggest that EPS contributes to occlusion and attachment of particulate organic matter (POM) in sandy soil aggregates. The application of a highly concentrated mix of $\alpha$-glucosidase, $\beta$-galactosidase, DNAse and lipase is related to a slight detachment of POM from a stable to a more fragile binding structure but not to an increase in POM release without physical disruption of aggregates by sonication. The pattern of measured light fraction soil organic carbon (LFSOC) release and additional bacterial DNA release points to an intra-aggregate fixation of POM by enzyme targets. A loss of EPS integrity could therefore cause a detachment of soil organic matter, not only in the laboratory but also in tilled soils. Our results further suggest that a change of the biofilm composition probably due to a shift in microbial population structure may alter soil aggregate stability. On macro-scale this could affect soil compactibility, erodibility, water transport, retention and aeration regime, rooting depth, and the occlusion of soil organic carbon. In conclusion, soil EPS dynamics could be considered a factor of sustainable land use.

\section{The Supplement related to this article is available online at doi:10.5194/soil-2-499-2016-supplement.}

Acknowledgements. This project was financially supported by the Leibniz Association (SAW Pact for Research, SAW-2012ATB-3). We also are grateful to Ulrich Szewzyk and the helpful staff of the Chair of Environmental Microbiology (Department of Environmental Technology, TU Berlin) for the unbureaucratic possibility to use their laboratories. In addition our thanks go out to Lara Schneider. Her bachelor thesis helped us to get an overview in the early phase of this experiment. And thanks both to Dennis Prieß for initiating a good idea during a very good Taiji training and to Tom Grassmann for his help in handling the R coding.

Edited by: S. Doerr

Reviewed by: M. Redmile-Gordon and one anonymous referee

\section{References}

Abröll, C., Kurth, T., Langer, T., Munk, K. and Nethe-Jaenchen, R.: Biochemie-Zellbiologie, Georg Thieme Verlag, 2008.

Absolom, D. R., Lamberti, F. V., Policova, Z., Zingg, W., van Oss, C. J., and Neumann, A.: Surface thermodynamics of bacterial adhesion, Appl. Environ. Microbiol., 46, 90-97, 1983.

Acosta-Martinez, V. and Tabatabai, M.: Enzyme activities in a limed agricultural soil, Biol. Fert. Soils, 31, 85-91, 2000.

Agnelli, A., Ascher, J., Corti, G., Ceccherini, M. T., Nannipieri, P., and Pietramellara, G.: Distribution of microbial communities in a forest soil profile investigated by microbial biomass, soil respiration and DGGE of total and extracellular DNA, Soil Biol. Biochem., 36, 859-868, 2004.

Alaoui, A., Lipiec, J., and Gerke, H.: A review of the changes in the soil pore system due to soil deformation: A hydrodynamic perspective, Soil Till. Res., 115-116, 1-15, 2011.

Ashman, M., Hallett, P., Brookes, P., and Allen, J.: Evaluating soil stabilisation by biological processes using step-wise aggregate fractionation, Soil Till. Res., 102, 209-215, 2009.

Baldock, J.: Interactions of organic materials and microorganisms with minerals in the stabilization of soil structure, in: Interactions between Soil Particles and Microorganisms - Impact on the 
Terrestrial Ecosystem, John Wiley\&Sons, Ltd: Chichester, West Sussex, UK, 84-129, 2002.

Ball, B. and Robertson, E.: Effects of uniaxial compaction on aeration and structure of ploughed or direct drilled soils, Soil Till. Res., 31, 135-148, 1994.

Barthes, B. and Roose, E.: Aggregate stability as an indicator of soil susceptibility to runoff and erosion; validation at several levels, Catena, 47, 133-149, 2002.

Battin, T. J., Sloan, W. T., Kjelleberg, S., Daims, H., Head, I. M., Curtis, T. P., and Eberl, L.: Microbial landscapes: new paths to biofilm research, Nat. Rev. Microbiol., 5, 76-81, 2007.

Baumgartl, T. and Horn, R.: Effect of aggregate stability on soil compaction, Soil Till. Res., 19, 203-213, 1991.

Bengough, A. and Mullins, C.: Mechanical impedance to root growth: a review of experimental techniques and root growth responses, J. Soil Sci., 41, 341-358, 1990.

Bennie, A. and Burger, R. D. T.: Penetration resistance of fine sandy apedal soils as affected by relative bulk density, water content and texture, South African Journal of Plant and Soil, 5, 5-10, 1988.

Böckelmann, U., Szewzyk, U. and Grohmann, E.: A new enzymatic method for the detachment of particle associated soil bacteria, J. Microbiol. Meth., 55, 201-211, 2003.

Bratbak, G. and Dundas, I.: Bacterial dry matter content and biomass estimations, Appl. Environ. Microbiol., 48, 755-757, 1984.

Brauns, A.: Praktische Bodenbiologie, G. Fischer Verlag, Stuttgart, Germany, 1-470, 1968.

Brodowski, S., John, B., Flessa, H., and Amelung, W.: Aggregateoccluded black carbon in soil, Eur. J. Soil Sci., 57, 539-546, 2006.

Bronick, C. J. and Lal, R.: Soil structure and management: a review, Geoderma, 124, 3-22, 2005.

Brown, G. G., Barois, I., and Lavelle, P.: Regulation of soil organic matter dynamics and microbial activityin the drilosphere and the role of interactionswith other edaphic functional domains, Eur. J. Soil Biol., 36, 177-198, 2000.

Burns, R. G., DeForest, J. L., Marxsen, J., Sinsabaugh, R. L., Stromberger, M. E., Wallenstein, M. D., Weintraub, M. N., and Zoppini, A.: Soil enzymes in a changing environment: current knowledge and future directions, Soil Biol. Biochem., 58, 216234, 2013.

Cerli, C., Celi, L., Kalbitz, K., Guggenberger, G., and Kaiser, K.: Separation of light and heavy organic matter fractions in soil - Testing for proper density cut-off and dispersion level, Geoderma, 170, 403-416, 2012.

Chaudhari, P. R., Ahire, D. V., Ahire, V. D., Chkravarty, M., and Maity, S.: Soil bulk density as related to soil texture, organic matter content and available total nutrients of Coimbatore soil, International Journal of Scientific and Research Publications, 3, $1-8,2013$.

Chenu, C. and Stotzky, G.: Interactions between microorganisms and soil particles: an overview, in: Interactions between Soil Particles and Microorganisms: Impact on the Terrestrial Ecosystem, IUPAC Series on Analytical and Physical Chemistry of Environmental Systems, 1-40, 2002.

Cooper, A. and Morgan, H.: Improved fluorometric method to assay for soil lipase activity, Soil Biol. Biochem., 13, 307-311, 1981.
Das, T., Sehar, S., Koop, L., Wong, Y. K., Ahmed, S., Siddiqui, K. S., and Manefield, M.: Influence of calcium in extracellular DNA mediated bacterial aggregation and biofilm formation, PloS one, 9, e91935, doi:10.1371/journal.pone.0091935, 2014.

Davey, M. E. and O’toole, G. A.: Microbial biofilms: from ecology to molecular genetics, Microbiol. Mol. Biol. R., 64, 847-867, 2000.

DeFlaun, M. F., Paul, J. H., and Jeffrey, W. H.: Distribution and molecular weight of dissolved DNA in subtropical estuarine and oceanic environments, Mar. Ecol.-Prog. Ser., 38, 65-73, 1987.

Eivazi, F. and Tabatabai, M.: Glucosidases and galactosidases in soils, Soil Biol. Biochem., 20, 601-606, 1988.

Eusterhues, K., Wagner, F. E., Häusler, W., Hanzlik, M., Knicker, H., Totsche, K. U., Kögel-Knabner, I., and Schwertmann, U.: Characterization of ferrihydrite-soil organic matter coprecipitates by X-ray diffraction and Mossbauer spectroscopy, Environ. Sci. Technol., 42, 7891-7897, 2008.

Flemming, H.-C. and Wingender, J.: The biofilm matrix, Nat. Rev. Microbiol., 8, 623-633, 2010.

Golchin, A., Oades, J., Skjemstad, J., and Clarke, P.: Study of free and occluded particulate organic matter in soils by solid state 13C CP/MAS NMR spectroscopy and scanning electron microscopy, Soil Research, 32, 285-309, 1994.

Imeson, A. and Vis, M.: Assessing soil aggregate stability by waterdrop impact and ultrasonic dispersion, Geoderma, 34, 185-200, 1984.

Jahn, A., Griebe, T., and Nielsen, P. H.: Composition of Pseudomonas putida biofilms: accumulation of protein in the biofilm matrix, Biofouling, 14, 49-57, 1999.

Jastrow, J. and Miller, R.: Soil aggregate stabilization and carbon sequestration: feedbacks through organomineral associations, in: Soil processes and the carbon cycle, CRC Press Boca Raton, FL, 207-223, 1997.

Joergensen, R. G.: The fumigation-extraction method to estimate soil microbial biomass: calibration of the $\mathrm{k}$ EC value, Soil Biol. Biochem., 28, 25-31, 1996.

Kaiser, M. and Berhe, A. A.: How does sonication affect the mineral and organic constituents of soil aggregates? - A review, J. Plant Nutr. Soil Sc., 177, 479-495, 2014.

Kalbitz, K., Solinger, S., Park, J.-H., Michalzik, B., and Matzner, E.: Controls on the dynamics of dissolved organic matter in soils: a review, Soil Sci., 165, 277-304, 2000.

Lal, R.: Sequestration of atmospheric $\mathrm{CO}_{2}$ in global carbon pools, Energ. Environ. Sci., 1, 86-100, 2008.

Li, B. and Logan, B. E.: Bacterial adhesion to glass and metal-oxide surfaces, Colloid. Surface. B, 36, 81-90, 2004.

Lieleg, O. and Ribbeck, K.: Biological hydrogels as selective diffusion barriers, Trends Cell Biol., 21, 543-551, 2011.

Lützow, M. v., Kögel-Knabner, I., Ekschmitt, K., Matzner, E., Guggenberger, G., Marschner, B., and Flessa, H.: Stabilization of organic matter in temperate soils: mechanisms and their relevance under different soil conditions - a review, Eur. J. Soil Sci., 57, 426-445, 2006.

Marchesi, J. R., Sato, T., Weightman, A. J., Martin, T. A., Fry, J. C., Hiom, S. J., and Wade, W. G.: Design and evaluation of useful bacterium-specific PCR primers that amplify genes coding for bacterial 16S rRNA, Appl. Environ. Microbiol., 64, 795-799, 1998. 
Margesin, R., Zimmerbauer, A., and Schinner, F.: Soil lipase activity - a useful indicator of oil biodegradation, Biotechnol. Tech., 13, 859-863, 1999.

Margesin, R., Zimmerbauer, A., and Schinner, F.: Monitoring of bioremediation by soil biological activities, Chemosphere, 40, 339-346, 2000

More, T., Yadav, J., Yan, S., Tyagi, R., and Surampalli, R.: Extracellular polymeric substances of bacteria and their potential environmental applications, J. Environ. Manag., 144, 1-25, 2014.

Munk, K.: Biochemie-Zellbiologie, Georg Thieme Verlag, Stuttgart, Germany, 1-576, 2008.

Muyzer, G., De Waal, E. C., and Uitterlinden, A. G.: Profiling of complex microbial populations by denaturing gradient gel electrophoresis analysis of polymerase chain reaction-amplified genes coding for 16S rRNA, Appl. Environ. Microb., 59, 695$700,1993$.

Niemeyer, J. and Gessler, F.: Determination of free DNA in soils, J. Plant Nutr. Soil Sc., 165, 121-124, 2002.

North, P.: Towards an absolute measurement of soil structural stability using ultrasound, J. Soil Sci., 27, 451-459, 1976.

Nunan, N., Wu, K., Young, I. M., Crawford, J. W., and Ritz, K.: Spatial distribution of bacterial communities and their relationships with the micro-architecture of soil, FEMS Microbiol. Ecol., 44, 203-215, 2003.

Oades, J.: The role of biology in the formation, stabilization and degradation of soil structure, Geoderma, 56, 377-400, 1993.

Or, D., Smets, B. F., Wraith, J., Dechesne, A., and Friedman, S.: Physical constraints affecting bacterial habitats and activity in unsaturated porous media - a review, Adv. Water Resour., 30, 1505-1527, 2007.

Pal, A. and Paul, A.: Microbial extracellular polymeric substances: central elements in heavy metal bioremediation, Indian J. Microbiol., 48, 49-64, 2008.

Pietramellara, G., Ascher, J., Borgogni, F., Ceccherini, M., Guerri, G., and Nannipieri, P.: Extracellular DNA in soil and sediment: fate and ecological relevance, Biol. Fert. Soils, 45, 219-235, 2009.

Pokrovsky, O. S., Dupré, B., and Schott, J.: Fe-Al-organic colloids control of trace elements in peat soil solutions: results of ultrafiltration and dialysis, Aquat. Geochem., 11, 241-278, 2005.

Redmile-Gordon, M., Brookes, P., Evershed, R., Goulding, K., and Hirsch, P.: Measuring the soil-microbial interface: Extraction of extracellular polymeric substances (EPS) from soil biofilms, Soil Biol. Biochem., 72, 163-171, 2014.

Redmile-Gordon, M., Evershed, R., Hirsch, P., White, R., and Goulding, K.: Soil organic matter and the extracellular microbial matrix show contrasting responses to $\mathrm{C}$ and $\mathrm{N}$ availability, Soil Biol. Biochem., 88, 257-267, 2015.
Rillig, M. C.: Arbuscular mycorrhizae, glomalin, and soil aggregation, Can. J. Soil Sci., 84, 355-363, 2004.

Schmidt, M., Rumpel, C., and Kögel-Knabner: Evaluation of an ultrasonic dispersion procedure to isolate primary organomineral complexes from soils, Eur. J. Soil Sci., 50, 87-94, 1999.

Schmitt, J. and Flemming, H.-C.: Water binding in biofilms, Water Sci. Technol., 39, 77-82, 1999.

Six, J., Conant, R., Paul, E. A., and Paustian, K.: Stabilization mechanisms of soil organic matter: implications for C-saturation of soils, Plant Soil, 241, 155-176, 2002.

Six, J., Bossuyt, H., Degryze, S., and Denef, K.: A history of research on the link between (micro) aggregates, soil biota, and soil organic matter dynamics, Soil Till. Res., 79, 7-31, 2004.

Skidmore, E. and Powers, D.: Dry soil-aggregate stability: energybased index, Soil Sci. Soc. Am. J., 46, 1274-1279, 1982.

Stewart, P. S.: A review of experimental measurements of effective diffusive permeabilities and effective diffusion coefficients in biofilms, Biotechnol. Bioeng., 59, 261-272, 1998.

Sutherland, I. W.: Biofilm exopolysaccharides: a strong and sticky framework, Microbiology, 147, 3-9, 2001.

Tang, J., Mo, Y., Zhang, J., and Zhang, R.: Influence of biological aggregating agents associated with microbial population on soil aggregate stability, Appl. Soil Ecol., 47, 153-159, 2011.

Taylor, H. and Brar, G.: Effect of soil compaction on root development, Soil Till. Res., 19, 111-119, 1991.

Tisdall, J.: Fungal hyphae and structural stability of soil, Soil Research, 29, 729-743, 1991.

Tisdall, J. and Oades, J.: Organic matter and water-stable aggregates in soils, J. Soil Sci., 33, 141-163, 1982.

Walker, S. L., Fourgialakis, M., Cerezo, B., and Livens, S.: Removal of Microbial Biofilms from Dispense Equipment: The Effect of Enzymatic Pre-digestion and Detergent Treatment, J. I. Brewing, 113, 61-66, 2007.

Watts, C. W., Whalley, W. R., Brookes, P. C., Devonshire, B. J., and Whitmore, A. P.: Biological and physical processes that mediate micro-aggregation of clays, Soil Science, 170, 573-583, 2005.

Weng, L., Temminghoff, E. J., Lofts, S., Tipping, E., and Van Riemsdijk, W. H.: Complexation with dissolved organic matter and solubility control of heavy metals in a sandy soil, Environ. Sci. Techno., 36, 4804-4810, 2002.

Wright, S. and Upadhyaya, A.: A survey of soils for aggregate stability and glomalin, a glycoprotein produced by hyphae of arbuscular mycorrhizal fungi, Plant Soil, 198, 97-107, 1998.

Zhang, X., Bishop, P. L., and Kupferle, M. J.: Measurement of polysaccharides and proteins in biofilm extracellular polymers, Water Sci. Technol., 37, 345-348, 1998. 